\title{
Species composition, abundance pattern of Bemisia tabaci and its co-inhibitant on eggplants under different chemical fertilization condition
}

\author{
1,*Mohd Rasdi, Z., ${ }^{2}$ Mohd Fozi, A., ${ }^{3}$ Che Salmah, M.R. and ${ }^{3}$ Hamady, D. \\ ${ }^{1}$ Faculty of Plantation and Agrotechnology, Universiti Teknologi MARA, Cawangan Melaka, Jasin Campus, \\ Melaka, Malaysia \\ ${ }^{2}$ Faculty of Civil Engineering, Universiti Teknologi MARA, 40450, Shah Alam, Selangor Malaysia \\ ${ }^{3}$ School of Biological Sciences, Universiti Sains Malaysia, Penang, Malaysia \\ ${ }^{4}$ Mosquito Research and Control Unit, 99, Red Gate Road, George Town, Grand Cayman KY1 - 1106 , \\ Cayman Islands
}

\author{
Article history: \\ Received: 23 July 2020 \\ Received in revised form: 4 \\ December 2020 \\ Accepted: 26 December 2020 \\ Available Online: 31 \\ December 2020
}

Keywords:

Bemisia tabaci,

Competitor pest,

Eggplant,

Acarines

DOI:

https://doi.org/10.26656/fr.2017.4(S5).022

\begin{abstract}
This study assesses the interaction, relationship and recorded several species of insectacarines pest on the underside of eggplant leaves. Variation of infestation levels by a community of insect-acarines detected on the leaves namely Whitefly Bemisia tabaci, aphids Myzus persicae, thrips Thrips palmi, mite and spider mite Tetranychus cinnabarinus caused serious damage at the initial stage of plant growth with flowering and fruiting stage. Different effects by fertilizer levels were observed affected the presence of insect-acarines and dominancy of major pest. The result also showed that all the insectspest was colonized competitively on the leaves for every sampling date due to treatments effect. Whitefly was found to be the most dominant on eggplants which resulted in more than $50 \%$ from other insect pest composition, particularly at higher fertilizer levels. Some occasions described that the predator-prey relationship has been identified as a major role in the habitat competition. There was an obvious trend of competitor pest of whitefly such as aphids' population was found higher than whitefly in all treatments. Generally, this study suggests that the dominant species and the first invader probably could suppress or mediate the other competitor significantly once they occupied on the same quality of host plants.
\end{abstract}

\section{Introduction}

Several insect pest species were found to infest eggplants (Khoo et al., 1991; Prabhu et al., 2009). Among them, few species cause some depress and damage to host plant from slight to serious. B. tabaci, aphids Myzus persicae, thrips Thrips palmi, mite and spider mite Tetranychus cinnabarinus cause serious damage at various stages of plant growth. The common insects that always attack this crop are leaf-feeding ladybird beetle (Epilachna indica), fruit and shoot borer (Leucinodes orbonalis), green peach aphid (M. persicae), red spider mite (T. cinnabarinus) and thrips (T. palmi) (Khoo et al., 1991). The interaction among insect-pest distinctively affected the population of its major pest, whitefly during the development and plant growth. Whitefly, Bemisia tabaci Gennadius (Homoptera: Aleyrodidae) has been destructive on many varieties of plants (Li et al., 2011) particularly in lowland agriculture area of Malaysia. There are very difficult to control the major pest, whitefly especially on brinjal plants due to the biological behaviour as the whitefly preferred living on the lower surfaces of leaves for feeding, mating, ovipositing and larval development (Coudriet et al., 1985). M. persicae has many host plants such as eggplant, broccoli, cabbage, sweet potato and tomato. It has a very complex life cycle and has been found on more than 800 plant species (Mau and Kessing, 2000). Feeding by Myzus persicae causes the leaves to become curl, distorted and yellow, and drop prematurely from the plant. When abundant, aphid feeding is likely a whitefly symptom that resulted in excretion of large amounts of honeydew, which would support the growth of a black sooty mould that causes spotting of leaves and fruits. As whitefly does, diseases caused by aphid are also able to spread viruses namely Potato Leaf Roll Virus and Potato Virus Y (Godfrey et al., 2002).

Cost of pest control strongly influenced by plants damage depends on the population of pests such as 
whitefly and several others. Fundamental understanding on the insect-acarine pest interaction such as whitefly and other pests on brinjal plants might be related to several factors (Horowitz et al., 1984; Gerling et al., 1986; Mohd Rasdi et al., 2009). Many empirical and theoretical studies that relate the species diversity (Aquilino et al., 2005) in various trophic levels affect the insect-pest population with the plants. The climatic factor that could change from time to time also affects the population and biology of whitefly and other insectpests. Therefore, the understanding of the underlying of all insect-pest distribution and relationship is important to develop a good strategy in controlling theses pest especially the whitefly (Nomikou et al., 2001; Li et al., 2011). Relationship between Infestations of insectspecies at several trophic levels and potential chemical defence by plants and natural enemies' intensity in agricultural ecology generate ideal opportunities to understand the community ecology accurately resulting manipulation of control techniques. A total of nineteen species of insects belonging to four families (Chrysopidae, Miridae, Anthocoridae and Coccinellidae) and eleven species of mites belonging to two families (Phytoseiidae and Stigmaeidae) are recorded as being effective predators to B. tabaci (Gerling, 1990). The predators of whitefly include assassin bug ( $M$. caliginosus), lady beetles (Delphastus sp. and Nephaspis sp.), green lacewings (Chrysopa sp. and Chrysoperla sp.), minute pirate bugs (Orius sp.), big-eyed bugs (Geocoris sp.), and damsel bugs (Nabis sp.). A total of twenty-eight species were recorded as parasitoids of $B$. tabaci include Aphelinidae (Aphelosoma: 1 species, Encarsia: 20 species, Eretmocerus: 6 species), and Platygasteridae (Amitus: 1 species) (Lopez-Avila, 1986; Gerling, 1990). Females of tiny parasitic wasps lay their eggs inside whitefly nymphs. When the wasps' eggs hatch, the larvae feed internally on the whitefly nymphs, eventually killing the host (Bogran and Heinz, 2000).

Conventional biological control programmes have been carried out against some whitefly species such as the silver leaf whitefly, citrus whitefly, and giant whitefly (Bogran and Heinz, 2000). The potential of using biological control agents has been examined in only a few species such as Delphastus catalinae and Serangium parcesetosum (Coccinellidae), Macrolophus caliginosus (Miridae), Chrysopela carnea and Chrysoperla rufilabris (Chrysopidea) (Gerling et al., 2001). There is general hypotheses could be developed in this study; the relationships of pest, natural enemies and host plant in a multitrophic system are densitydependent. To achieve the objectives of the study, some question have been tested such as does different nutrient levels applied on eggplants affect pest, competitor pest and natural enemy populations? And does the coexistence of pest, natural enemies generate significant natural reactions to stabilize their ecosystem? The activity of all insects-pests on the leaves had shaped different scenario and trend on how they interact and compete with each other for food, oviposition site and shelter. Therefore, the study was carried out to determine the presence of whitefly population and its competitor as well as acarines on the leaves of the eggplant. This objective is focused on the relationship among them and the influence of abundance and domination major pest on brinjal leaves. Therefore, the understanding of the underlying of all insect-pest distribution and relationship is important and highly needed for the development of a good control strategy (Nomikou et al., 2001; Li et al., 2011). Thus, generate ideal opportunities to understand the community ecology accurately and clearly.

\section{Materials and methods}

\subsection{Study area}

This experiment was carried out for two cropping periods at Agriculture Centre, Relau, Pulau Pinang, Malaysia with three months sampling period from August to October 2016 and between February to May 2017 for first and second cropping respectively. This study was carried out under rain shelter to protect the eggplant (Solanum melongena L.) plants from rainfall and equipped with a fertigation system that practised identically by eggplant growers. This crop is suitable to grow under rain shelter and it can be planted in polybags (soil-less medium) on any available area even unfertile soil area and produces more yield (Seminar Paper, MARDI $\mathrm{CH}$ ). Malaysia has year-round equatorial climate and high of rainfall with a relative humidity of $70-85 \%$ and temperature of $28 \pm 5^{\circ} \mathrm{C}$. All further laboratory studies including sorting, counting and identification of specimens were carried out in Entomology Laboratory, Crop Protection Department, Universiti Teknologi MARA Jasin Campus, Malaysia. The selected F1-hybrid eggplant seeds were sown in 104 seedling trays at nursery that covered by wire net to avoid undesirable insect infestation.

\subsection{Preparation of experimental plot using fertigation system}

Standard agronomic practices such as drip irrigation, seed germination, fertilization, pruning and harvesting were employed in this study for ideal growth of eggplant and normal distribution of Bemisia tabaci and its natural enemies. The selection of nutrient composition was based on the common practices recommended by MARDI (Manual Highland Tomato, MARDI, 2004). Nutrient concentration was measured using a portable 
TD Scan and $\mathrm{pH}$ was estimated by a $\mathrm{pH}$ Scan1 to determine the optimum level of $\mathrm{pH}$ for plant growth, which ranged from 5.5 to 7.0. 4-week-old eggplant seedlings were transplanted carefully into polybags $(30 \times 30 \mathrm{~cm})$, containing burnt rice husk, with a one-meter distance between plants and one meter between rows. The polybags were arranged in five blocks under rain shelter equipped with a fertigation system. After transplanting, the plants were supplied with nutrients mixed with water three times a day (morning, afternoon and evening) using a drip irrigation system (fertigation system) throughout the growing period. An electric timer water pump was used to fertigate (water and nutrients) the plants. Each plant was supported by plastic ropes when the plants started to produce fruit.

\subsection{Treatments}

Application of three concentrations of nutrients on eggplant is summarized in Table 1 .

Table 1. Two treatments (nutrient concentration and preinfestation of seedlings) combination of the study treated on eggplants

\begin{tabular}{ll} 
N1TC & N1 $=50 \mathrm{ppm} ; \mathrm{TC}=$ Non pre-infested \\
N2TC & N2 $=150 \mathrm{ppm} ; \mathrm{TC}=$ Non pre-infested \\
N3TC & N3 $=300 \mathrm{ppm} ; \mathrm{TC}=$ Non pre-infested \\
\hline
\end{tabular}

\subsubsection{Application of nutrients on eggplants and their preparation}

In this field trial, three dosages of nutrients $(\mathrm{N} 1=50$ $\mathrm{ppm}=0.05 \mathrm{~g} / \mathrm{L}, \mathrm{N} 2=150 \mathrm{ppm}=0.150 \mathrm{~g} / \mathrm{L}, \mathrm{N} 3=300$ $\mathrm{ppm}=0.300 \mathrm{~g} / \mathrm{L}$ ) with $\mathrm{pH}$ of 5.8-6.8 were applied on eggplant, transplanted onto the beds under rain shelter for entire cropping period to determine their effect on the population of whiteflies. All the fertigation system including piping line, emitters and water pump was automatically set up at three times a day; 0900 a.m., 1200 p.m. and 1700 p.m. for 5 minutes for each application. Three concentrations of nutrients were prepared weekly and measured daily by portable TDscan4. To ensure ideal growth and development of the plants, they were irrigated with fresh water once a week to leach minerals accumulating in the planting media. All raw materials of fertilizer were supplied by the Department of Agriculture (DOA). Nutrients were prepared at fertigation-pump-house located at the experimental plot. The concentration of $\mathrm{N}_{2}(150 \mathrm{ppm})$ is recommended by the Department of Agriculture (DOA) and Malaysia Agriculture Research and Development Institute (MARDI). Initially, the high concentration solution of nutrients was classified into two groups (set A) and (set B) to dilute with water efficiently. Calcium nitrate $(\mathrm{Cn}-900 \mathrm{~g} / 46 \%)$ and Iron Edta (Fe-41.6 g/ $2.15 \%$ ) were provided as Set $\mathrm{A}$, and potassium nitrate
(Pn-152 g/ 7.87\%), magnesium sulphate $\left(\mathrm{MgSO}_{4}-500 \mathrm{~g} /\right.$ $25.89 \%)$, potassium chloride $(320 \mathrm{~g} / 16.57 \%)$, phosphoric acid (13.6 g/ $0.7 \%)$, zinc sulphate $(0.1 \mathrm{~g} /$ $0.05 \%)$, cuprum sulphate $(0.1 \mathrm{~g} / 0.05 \%)$, ammonium molibdate $(0.4 \mathrm{~g} / 0.02 \%)$, manganese sulphate $(2 \mathrm{~g} /$ $0.103 \%)$, and boric acid (1.4 g/ 0.072\%) were prepared as Set B (Table 2). Subsequently, sets A and B were separately diluted with 50-litre water in small reservoir tanks and labelled as a high concentration of solutions A and $\mathrm{B}$, respectively. All the fertilizer prepared were standardised and diluted in 1000 litre water. Different concentrations of nutrients were prepared by mixing and diluting the nutrients prepared earlier with water in labelled tanks separately such as Tank 1 (N1-50 ppm), Tank 2 (N2-150 ppm) and Tank 3 (300 ppm).

Table 2. Composition and quantity of nutrient requirement for eggplants (recommended by the Agriculture Department)

\begin{tabular}{lc}
\hline Nutrients & Quantity in 1000 litre water \\
\hline Calcium Nitrate & $900 \mathrm{~g}$ \\
Potassium Nitrate & $152 \mathrm{~g}$ \\
Potassium Chloride & $320 \mathrm{~g}$ \\
Magnesium Sulphate & $500 \mathrm{~g}$ \\
Phosphoric Acid & $136 \mathrm{~mL}$ \\
Fe EDTA & $41.6 \mathrm{~g}$ \\
Zinc Sulphate & $0.1 \mathrm{~g}$ \\
Cuprum Sulphate & $0.1 \mathrm{~g}$ \\
Boric Acid & $1.4 \mathrm{~g}$ \\
Ammonium Molibdate & $0.4 \mathrm{~g}$ \\
Manganese Sulphate & $2.0 \mathrm{~g}$ \\
\hline
\end{tabular}

\subsection{Data collection}

The data for whitefly abundance and other insects on the leaves were counted under a stereomicroscope. Every two-week data collection was commenced from the second week after transplanting (WAT) until the end of harvesting for two cropping periods. The samples were collected in the morning, as early as 0900 to 1000 for each block ( 3 treatments of nitrogen level $\mathrm{x} 5$ replicates per treatment) with a total of 15 samples of leaves' discs at two weeks interval. A sample consists of three leaves discs collected one at a time, from the middle stratum (Mohd Rasdi et al., 2009) of a host plant in treatment for each block. The leaf was inserted into a zip-lock plastic bag and the petiole cut off and the bag fastened. All the samples were brought back to the Entomology Laboratory.

\subsection{Data analysis}

All data were transformed to meet assumptions of normality and homogeneity of variance. Observation on two stages of plant growth was carried out on the composition and relationship between whitefly as a major insect pest, competitor insect-acarines and natural enemies on treated host plants. Differences in weekly 
mean abundance of the whitefly, competitor insectacarine and natural enemy populations were analyzed using the two-way Analysis of Variance (ANOVA) (Sandra and Ramon, 1987) to assess the dependency of the two trophic components at different levels of nutrient applications and pre-infestation of seedlings. All values are presented as Means $( \pm)$ Standard Errors (S.E). All the results have been presented in the tables and graphs.

\section{Results}

3.1 Effect of Treatments Nutrient Concentration on Composition and Abundance of Insects Pest (Whitefly, Aphid, Thrips, Spider mite and Mite) Under Surface of Eggplant Leaf

In this study, Tables 3 and 4 indicate all the insectspest composition was observed that colonised competitively on the leaves for every sampling date according to treatments effect for first and second cropping periods. The results indicated that the potential treatment's effects on the interaction among herbivory as well as natural enemy's population influence directly or indirectly against various treatments treated on brinjal. Some of the insects-pest plays an important role in the same trophic level as a competitor due to their ability to influence the population of colonised insect-pest especially towards whitefly and in getting food, place and shelter. Species of insect-pest composition on eggplant leaves in all nine treatments were counted and recorded for both cropping periods. A total mean insect pest from the treatments was ranged from a minimum of 32.63/leaf to a maximum of 112.3/leaf, representing five insect-pest species were counted. Five insect-pests were identified namely whitefly (Bemisia tabaci), aphids, thrips, spider mite and mite. Tables 5 and 6 show relative abundance of insect pests on the eggplant leaves for first and second cropping period respectively. Whitefly was found to be the most dominant on plants which resulted in more than $50 \%$ from other insect pest composition such as treatments N3 (25.07 \pm 7.28$)$. While other insectpests such as aphids, thrips, spider mite and mite for both treatments (N3TC) were recorded less than 20\% composition. Overall, for the entire sampling period of first cropping, eggplant leaves which treated with N3TC showed the most dominant for whitefly $(54.65 \%)$, followed by aphids (17.01\%), mites (13.44\%), spider mite $(9.38 \%)$ and thrips (5.52\%). Eggplants were found to have a fair number of aphids and almost similar proportion among treatments. When comparing the population mean number of all insect-pest on the eggplant leaves, thrips were found to be the lowest in number and proportion of all insect pests in all treatments. Additionally, the percentage of thrips was ranging from $1.13 \%$ to $8.38 \%$ of all in insect-pests composition on the underside of leaves.

Meanwhile, mites were found to be the highest proportion and most dominant in treatments of N1TC and N2TC with population composition of $37.79 \%$ and $44.78 \%$ respectively. Some of the insect-pest population are not relying on the treatment's effect, possibly due to other factors such as the competition with other competitors as well as availability and ability of natural enemies in searching their preys on the eggplant's leaves. Generally, some insect pests' population were not much affected by the treatment of nutrient concentration but sometimes they were affected due to the predatorprey relationship (Table 7). Meanwhile, spider mite was observed to colonise just after mite infestation on the eggplant leaf for all treatments. It was also observed that

Table 3. Detection of insect-pests present on the eggplant leaves in first cropping

\begin{tabular}{|c|c|c|c|c|c|c|}
\hline \multirow{2}{*}{$\begin{array}{l}\text { Fertilizer Levels } \\
\text { Pest's Species } \\
\end{array}$} & \multicolumn{2}{|c|}{ N1 (50 ppm) } & \multicolumn{2}{|c|}{ N2 (150 ppm) } & \multicolumn{2}{|c|}{ N3 (300 ppm) } \\
\hline & Begin & End & Begin & End & Begin & End \\
\hline \multicolumn{7}{|l|}{ Non-sucking Pest } \\
\hline Mite & + & + & + & - & + & - \\
\hline$\underline{\text { Spidermite }}$ & + & + & + & - & + & - \\
\hline \multicolumn{7}{|l|}{ Sucking Pest } \\
\hline Whitefly & + & + & + & + & + & + \\
\hline Aphids & + & - & + & + & + & - \\
\hline Thrips & + & + & + & + & + & - \\
\hline
\end{tabular}

Table 4. Detection of insect-pests present on the eggplant leaves in second cropping

\begin{tabular}{|c|c|c|c|c|c|c|}
\hline \multirow{2}{*}{$\begin{array}{l}\text { Fertilizer Levels } \\
\text { Pest's Species } \\
\end{array}$} & \multicolumn{2}{|c|}{ N1 (50 ppm) } & \multicolumn{2}{|c|}{ N2 (150 ppm) } & \multicolumn{2}{|c|}{ N3 (300 ppm) } \\
\hline & Begin & End & Begin & End & Begin & End \\
\hline \multicolumn{7}{|l|}{ Non-sucking Pest } \\
\hline Mite & + & + & + & + & + & + \\
\hline Spidermite & + & + & + & + & + & - \\
\hline \multicolumn{7}{|l|}{ Sucking Pest } \\
\hline Whitefly & + & + & + & + & + & + \\
\hline Aphids & + & - & + & + & + & - \\
\hline Thrips & + & - & + & + & + & - \\
\hline
\end{tabular}


Table 5. Relative abundance of insect-pests on the eggplant leaves in first cropping

\begin{tabular}{lccc}
\hline Fertilizer & $\begin{array}{c}\mathrm{N} 1 \\
(50 \mathrm{ppm})\end{array}$ & $\begin{array}{c}\mathrm{N} 2 \\
(150 \mathrm{ppm})\end{array}$ & $\begin{array}{c}\mathrm{N} 3 \\
(300 \mathrm{ppm})\end{array}$ \\
\hline Pest's Species & & & \\
\hline Non-sucking Pest & & & \\
\hline Mite & 0.03 & 0.07 & 0.03 \\
Spidermite & 0.17 & 0.60 & 0.14 \\
\hline Sucking Pest & & & \\
\hline Whitefly & 0.59 & 0.26 & 0.77 \\
Aphids & 0.15 & 0.06 & 0.01 \\
Thrips & 0.06 & 0.02 & 0.05 \\
\hline Total Insect-Acarine (N) & 70.5 & 143.9 & 108.1 \\
\hline
\end{tabular}

Table 5. Relative abundance of insect-pests on the eggplant leaves in first cropping

\begin{tabular}{lccc}
\hline Fertilizer & $\begin{array}{c}\mathrm{N} 1 \\
(50 \mathrm{ppm})\end{array}$ & $\begin{array}{c}\mathrm{N} 2 \\
(150 \mathrm{ppm})\end{array}$ & $\begin{array}{c}\mathrm{N} 3 \\
(300 \mathrm{ppm})\end{array}$ \\
\hline Pest's Species & & & \\
\hline Non-sucking Pest & & & \\
\hline Mite & 0.03 & 0.07 & 0.05 \\
Spidermite & 0.03 & 0.03 & 0.01 \\
\hline Sucking Pest & & & \\
\hline Whitefly & 0.73 & 0.55 & 0.68 \\
Aphids & 0.11 & 0.07 & 0.07 \\
Thrips & 0.10 & 0.29 & 0.18 \\
\hline Total Insect (N) & 101.1 & 101.1 & 101.4 \\
\hline
\end{tabular}

Table 7. Correlations test between insect-pests on eggplant' leaf in first cropping

\begin{tabular}{|c|c|c|c|c|c|c|}
\hline & & Whitefly & Aphid & Thrips & Mite & Spidermite \\
\hline \multirow[t]{2}{*}{ Whitefly Population } & Pearson Correlation & 1 & $.219(* *)$ & $.231(* *)$ & 0.045 & 0.097 \\
\hline & Sig. (2-tailed) & & 0 & 0 & 0.458 & 0.11 \\
\hline \multirow[t]{2}{*}{ Aphid } & Pearson Correlation & $.219(* *)$ & 1 & $.317(* *)$ & $.209(* *)$ & $.228(* *)$ \\
\hline & Sig. (2-tailed) & 0 & & 0 & 0.001 & 0 \\
\hline \multirow[t]{2}{*}{ Thrips } & Pearson Correlation & $.231(* *)$ & $.317(* *)$ & 1 & $.316(* *)$ & $.218(* *)$ \\
\hline & Sig. (2-tailed) & 0 & 0 & & 0 & 0 \\
\hline \multirow[t]{2}{*}{$\overline{\text { Mite }}$} & Pearson Correlation & 0.045 & $.209(* *)$ & $316(* *)$ & 1 & $.487(* *)$ \\
\hline & Sig. (2-tailed) & 0.458 & 0.001 & 0 & & 0 \\
\hline \multirow[t]{2}{*}{ Spider mite } & Pearson Correlation & 0.097 & $.228(* *)$ & $.218(* *)$ & $.487(* *)$ & 1 \\
\hline & Sig. (2-tailed) & 0.11 & 0 & 0 & 0 & \\
\hline
\end{tabular}

** Correlation is significant at the 0.01 level (2-tailed).

spider mite aggressively attacked mites and reduced the population significantly in a few weeks. This scenario described that the predator-prey relationship has been identified as a major role in the habitat competition. Meanwhile, the proportion of immature thrips in the insect's composition was found to be the lowest population under the surface of leaves for all treatment. These probably might explain that the leaves are not the main places for their habitat suitability. In some cases, instead of flowers as the main habitat, leaves are also known as impermanent habitat before the flowering stage.

Table 8 summarizes the results of insect-pests for all nine treatments in the second cropping period. The highest total mean number of insect-pest was recorded in treatment N1 (70.77/leaf). The lowest was observed for treatments $\mathrm{N} 2$ (53.25/leaf). In the second cropping period, the population of whitefly was not much higher as aphids in all treatments. Both treatments N3 and N1 were recorded as a high tendency on whitefly population compared to the other treatments. It was also noted, in the second cropping, aphids were found to be the highest proportion and dominant in all treatments. This showed that an increase in nutrient concentration such as N2 and N3 had elevated numbers of whitefly. While other pests such as mite and spider mite were found greatly in their numbers during the first cropping. The population of whitefly in N2 was consistently lower compared to the other treatments. This phenomenon described that the competition exists obviously among whitefly, aphids and thrips for the two cropping periods. The finding suggested that one of the species could suppress or mediate the other competitor effectively once they live on the same quality of host plants. Results from both cropping periods demonstrated that aphids' population was found to be higher proportion consistently than whitefly in all treatments. All the insect pests were competing and had their own ability to compete among them especially between whitefly and aphid. This finding suggested that aphid is able to compete with whitefly in getting food, shelter and space. While the treated plants provide more favoured to compete and convenient environment for getting food and places for all insectpest. This study demonstrated that there was a significant relationship between whitefly and other competitor pests (Table 9). It could explain the fluctuation of the whitefly population was influenced significantly by competitor pest remarkably aphids and thrips. Nutrient treatment was commonly associated to plant performance and consequently showed whitefly population was significantly affected. However, result from this study on the same trophic level (especially competitor pest) and higher trophic level (such as predator) could also mediate 
Table 8. One-Way Analysis of Variance (ANOVA) and composition (\%) of all insects-pests (whitefly, aphids, thrips, spider mite, and mite) on eggplant leaves subjected to each treatment (treatment combination of nutrient concentration) for the entire sampling period of second cropping period

\begin{tabular}{lcccccc}
\hline \multicolumn{5}{c}{ Mean and Percentage of Insect Pest Population } \\
\hline Treatment & Whitefly & Aphids & Thrips & Mite & Spider mite & Total Mean Insect/Leaf \\
\hline \multirow{2}{*}{ N1TC } & $20.63 \pm 5.37^{\mathrm{bc}}$ & $36.76 \pm 15.59$ & $3.73 \pm 0.91^{\mathrm{a}}$ & $0.97 \pm 0.23$ & $0.97 \pm 0.34$ & 70.77 \\
& $-29.16 \%$ & $-66.75 \%$ & $-1.37 \%$ & $-1.37 \%$ & $-1.37 \%$ & $-100 \%$ \\
\hline \multirow{2}{*}{ N2TC } & $13.47 \pm 2.75^{\mathrm{ab}}$ & $43.63 \pm 22.52$ & $7.97 \pm 2.53^{\mathrm{b}}$ & $1.57 \pm 0.54$ & $0.77 \pm 0.27$ & 53.25 \\
& -25.29 & $-67.39 \%$ & $-2.94 \%$ & $-2.94 \%$ & $-1.44 \%$ & $-100 \%$ \\
\hline \multirow{2}{*}{ N3TC } & $26.03 \pm 5.92^{\mathrm{c}}$ & $25.4 \pm 10.14$ & $4.6 \pm 1.61^{\mathrm{ab}}$ & $1.93 \pm 0.34$ & $0.80 \pm 0.27$ & 67.22 \\
& $-38.73 \%$ & $-54.33 \%$ & $-2.88 \%$ & $-2.88 \%$ & $-1.19 \%$ & $-100 \%$ \\
\hline & $\mathrm{F}=3.80 ;$ & $\mathrm{F}=1.609 ;$ & $\mathrm{F}=2.313 ;$ & $\mathrm{F}=1.818 ;$ & $\mathrm{F}=2.624 ;$ & \\
& $\mathrm{df}=8,269 ;$ & $\mathrm{df}=8,269 ;$ & $\mathrm{df}=8,269 ;$ & $\mathrm{df}=8,269 ;$ & $\mathrm{df}=8,269 ;$ & \\
& $\mathrm{P}<0.01$ & $\mathrm{P}>0.05$ & $\mathrm{P}<0.05$ & $\mathrm{P}>0.05$ & $\mathrm{P}>0.01$ & \\
\hline
\end{tabular}

Value in each bracket is subjected to percentage of total volume in the row. Means within the column followed by the same superscript are not significantly different at $\mathrm{P}>0.05$ by DMRT.

Table 9. Correlations test between insect-pests on eggplant' leaf in second cropping

\begin{tabular}{llccccc}
\hline & & Whitefly & Aphid & Thrips & Mite & Spidermite \\
\hline \multirow{2}{*}{ Whitefly Population } & Pearson Correlation & 1 & $.185(* *)$ & $.451\left(^{* *}\right)$ & .037 & .015 \\
& Sig. (2-tailed) & & .002 & .000 & .542 & .809 \\
\hline \multirow{2}{*}{ Aphid } & Pearson Correlation & $.185(* *)$ & 1 & $.280(* *)$ & $-.197(* *)$ & .047 \\
& Sig. (2-tailed) & .002 & & .000 & .001 & .443 \\
\hline Thrips & Pearson Correlation & $.451(* *)$ & $.280\left(^{* *}\right)$ & 1 & $.154\left(^{*}\right)$ & .031 \\
& Sig. (2-tailed) & .000 & .000 & & .011 & .614 \\
\hline Mite & Pearson Correlation & .037 & $-.197(* *)$ & $.154(*)$ & 1 & -.035 \\
& Sig. (2-tailed) & .542 & .001 & .011 & & .569 \\
\hline Spider mite & Pearson Correlation & .015 & .047 & .031 & -.035 & 1 \\
& Sig. (2-tailed) & .809 & .443 & .614 & .569 & \\
\hline
\end{tabular}

** Correlation is significant at the 0.01 level (2-tailed). * Correlation is significant at the 0.05 level (2-tailed).

and suppressed the whitefly population in the field.

Figure 1 shows the results of all insect-pests reached a peak of the initial stage of plant growth either two or four weeks after transplanting in both cropping periods. Results from the studies show that insect pests in all treatments started to decrease dramatically after 6 WAT. The population and infestation trend of whiteflies were observed earlier stage, especially at 2 WAT. Aphids, mite and spider had reached a peak in number following whitefly infestation for both cropping periods. Despite the whitefly domination, aphids as the competitor were dominantly at peak at 4 WAT for the second cropping compared to the mite and spider mite population which more dominant during the first cropping. The finding described that aphids are found to be a major competitor pest to whitefly particularly in the second cropping, meanwhile, other pests appeared with low in number on plants early harvesting stage (after 6 WAT). Even though aphids could develop their population rapidly in the early season of cropping period, however, the population was more susceptible to other factors which caused sharply decreased compared to the whitefly. The entire insect pest had a lower number after 8 WAT and sometimes some insect-pest species had no infestation at all. However, the population of whitefly remains an abundance on the host plant and a mere species dominant found for subsequent weeks, even though in a low number. The findings suggested that whitefly is able to survive and maintain their population until the end of the sampling period.

\section{Discussion}

This study focusing more on the effects of treatments namely nutrient levels treated on the plants and preinfested eggplants by whitefly, aphids and free from pest's pre-infestation in order to evaluate the population of insect pest and its composition on the host plant. All the insects-pest composition was colonized competitively at the early stage of plant growth on the leaves for every sampling date regarding the effect of the treatment. These finding revealed the possible effects on the interaction among herbivory as well as natural enemies' population directly or indirectly against treatments. Some of the insects play an important role as a competitor in getting the food, place and shelter that consequently affect the colonization of the whitefly 

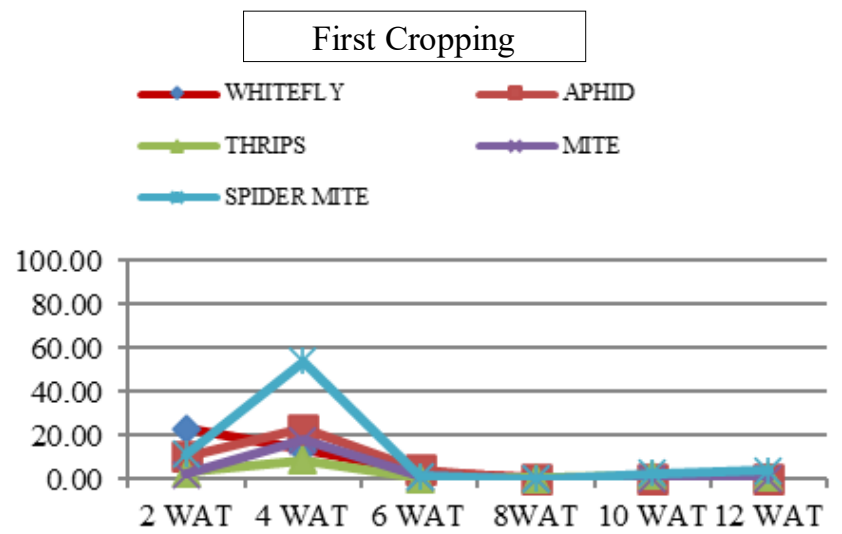

N1TC

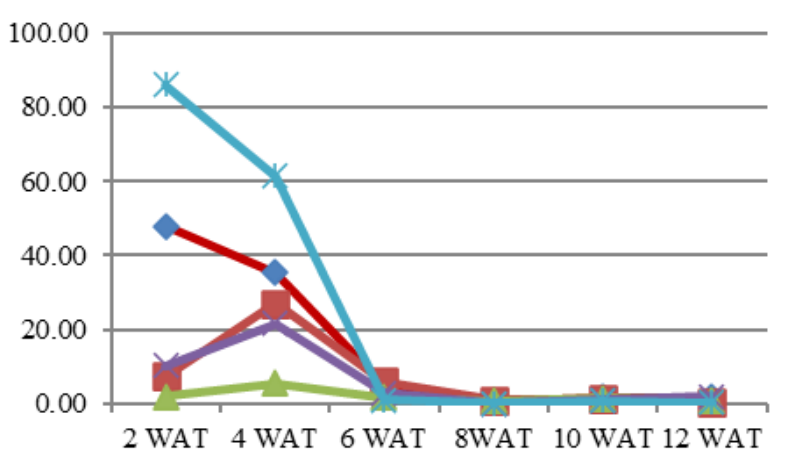

$\mathrm{N} 2 \mathrm{TC}$

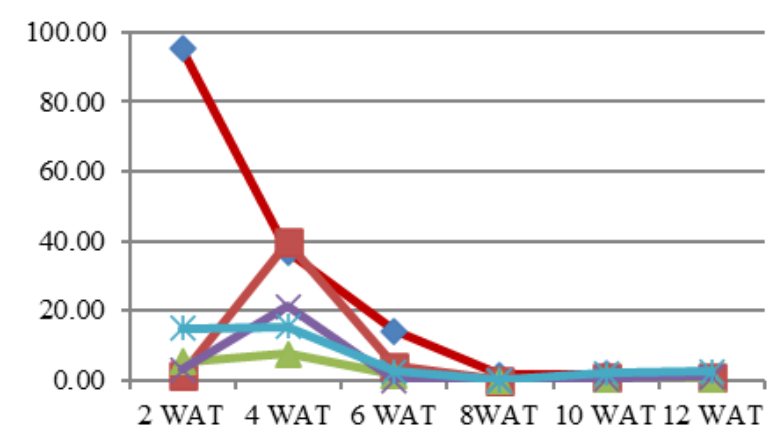

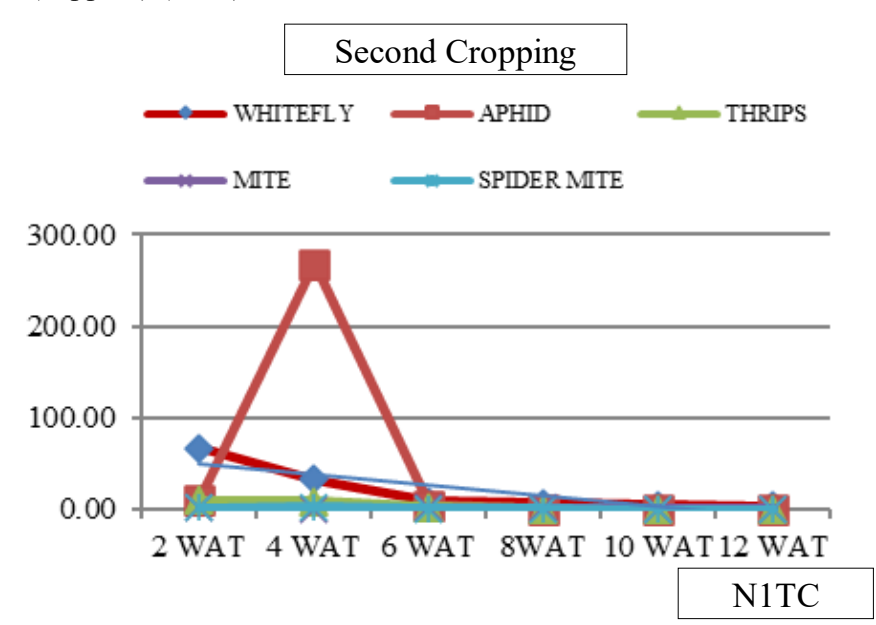

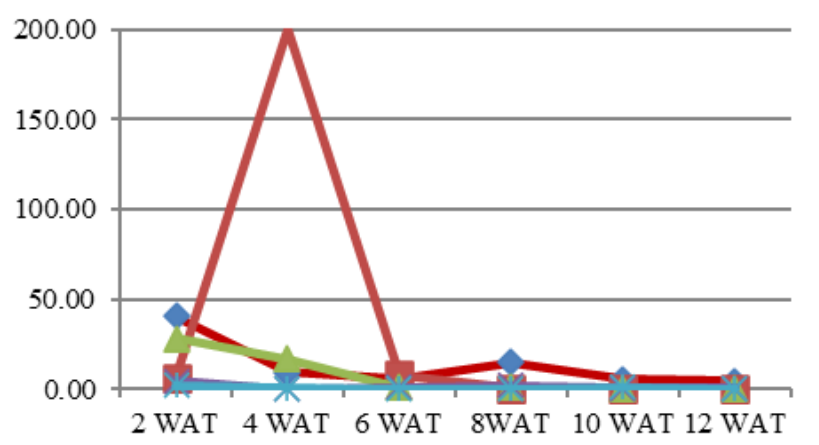

$\mathrm{N} 2 \mathrm{TC}$

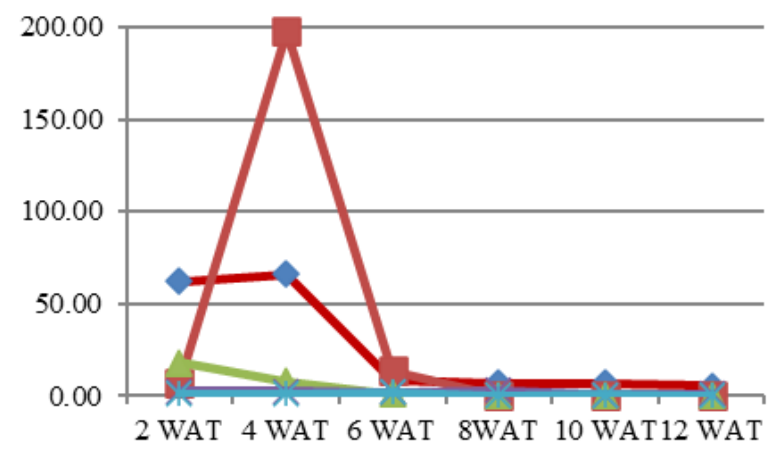

N3TC

Figure 1. Population dynamic of all insect pests found on eggplant leaves at every sampling week after transplanting (WAT) in the first and second cropping

population. In relation to this study, many species of insect-pest had infested on the treated eggplants in both cropping periods. There are many studies revealed that high diversity of insect-pest could modify the population fluctuation by either increase, reduce or mediate the insect-pest effect. One of the previous studies by Aquilino et al. (2005) suggested that the population sizes of the species could play an important role to disrupt the trophic system. Some activities have been recorded on how the plants treatment could reveal the possibility to mediate and change the structure of the community in the ecological system from the perspective of the plant itself. Therefore, the present study was carried out to understand the underlying of insect-pest on the eggplants through the spatial and temporal activities of outbreaks. This study may be required to go further than simple plant-herbivore dynamics and consider trophic density, ecological heterogeneity, limited dispersal, and their possible interactions (Harrison et al., 2005).

Besides whitefly, there are other insect pests and diseases infecting eggplant. The control methods such as cultural, biological and chemical are also different according to the species of insect pests and diseases outbreak on eggplant plant. There are many species of insects attacking eggplant, but the most common insect pest that always attacks this crop are leaf-feeding ladybird beetle (Epilachna indica), fruit and shoot borer (Leucinodes orbonalis), green peach aphid (Myzus persicae), red spider mite (Tetranychus cinnabarinus) and thrips (Thrips palmi) (Khoo et al., 1991). The crop losses of up to $50 \%$ due to whitefly infestation were 
noted for eggplant, capsicum, tomatoes and cucumber. For instance, in the Cameron Highlands, whitefly was found to be more serious on crops grown in the rain shelters as compared to tomatoes that are grown in the open (Syed Abdul Rahman et al., 2000). Results in both cropping periods found that there was an obvious trend of whitefly's competitor pest, aphids' population was found to be a higher proportion than whitefly in all treatments. Aphid population fluctuated and did not give consistent result particularly on the tendency or preference towards treated hostplant. This phenomenon is very difficult to make an inference on the proportion of the aphid population on the eggplant leaves. However, it is able to compete with whitefly in getting food, shelter and space in other treated plants such as non-infested plants and pre-infested by aphids for several weeks. While the other treated plants provide more convenient for getting food and places for all insect-pest, the entire insect pest especially between whitefly and aphid they were competing for each other. A few treatments gave effect to whitefly and competitor pest such as aphid, thrips and also other insect-pests with deceptive outbreaks in the field. Furthermore, whitefly and aphid caused significant physical damage to the plants as they combined attacked especially on eggplants (Data not shown).

Treatment of fertilizer levels seemed did not give significant effect to the population of thrips but it may possibly due to other competitors, or natural enemy's activities. Interestingly, thrips were found to have a significant relationship to whitefly. This indicates that the abundance of whitefly was greatly influenced by the presence of thrips on the eggplant leaves. Meanwhile, the treatments treated in the experimental plot also affected the thrips population. The finding of this study suggested that there is strong effects of herbivore diversity and other trophic levels (Pearson and Dyer, 2006) such as whitefly and thrips as a competitor had a negative correlation as they were competing among them in space and time. Agrawal et al. (1999) found that thrips started to feed on the plant and mites as competitor pest eats on the plant too. Mites' feeding activities caused plant producing secondary metabolites, consequently thrips less feed on the plant. As a result, the thrips changed its behaviour to attack and feed on mites. Even though the entire insects' pests in the study are sucking insect but they acted in different ways in competing and infested the plants. Sucking insect pests are more dominant and higher preference when the plants have been early infested by other pests. This scenario indicates that the treatments have similar systemic effects on the spider mite and mite populations on the respectively treated eggplants. This phenomenon described that there was probably had a mutual predator- prey relationship between spider mite and mite.

Even though plants are seen to be infested at the initial stage and caused physical damage but this study evidently showed that plants could mediate and able to defence after a few weeks particularly for healthy plants treated with optimum nutrient level $(150 \mathrm{ppm})$. The abundance of whitefly was also greatly influenced by the presence of competitor pests especially thrips on the eggplant leaves or possibly due to chemical defence induced by plants after infestation by herbivory activities (Takabayashi et al., 1991; Dicke and van Loon, 2000). Otherwise, competitor pest especially aphid and spider mite colonized undersurface of leaves did not show significant influence on the whitefly population. A high variation on the infestation timing of each insect pest on eggplants was detected. Therefore, the timing of infestation, distribution and population of whitefly and other insects relied on several factors such as the composition of insects' pest, host plants, climatic factors and migration of insects. An empirical study on the secondary metabolites as a defence system induced by plants after herbivory activity is required and should be studied to support the findings of the study. Hence, the interaction of insect-pest in the agriculture ecological system could be interfered by human factors during agronomic practices especially in the selection of nutrient levels and pest management system. The multitrophic system could change and affect the population of all insect-pests, especially in the experimental plot or agricultural ecology. This study recorded the inconsistencies of the population trend of each insect-pest species such as competitor pest aphids even on treated eggplants. Similarly, a study was done by Aquilino et al. (2005) reported that the population of aphid was not affected only by top-down effect, but also bottom-up effect. For instance, the increase of natural enemy diversity and plants species could affect the population of aphids.

\section{Conclusion}

Generally, when compared to with other competitor pests such as aphids and thrips, whitefly was found to be a major pest due to the special ability of whitefly to compete with unique strategies. This ability could sustain their population on the eggplant leaves throughout the cropping period. Instead of an indirect effect of nutrient towards pests, it can be concluded that the population of whitefly evidently had disrupted by other competitor pests naturally presence in agricultural ecology. This scenario described the interactions of a major pest species with other competitor pest species as they occupied the same host plants. Eggplants' performance was highly influenced by nutrients; therefore, different 
plant performance due to different nutrient levels had significantly influenced the population abundance of whitefly, aphid, thrips, mite and spider mite. Other than nutrient treatments' effects on host plants, the population of whitefly evidently regulated by other competitor pests naturally occurring in the field. High diversity of plant pests could modify the main pest population (whitefly) by either increasing or reducing and mediating the pest effect. When aphid co-exists to develop and compete with whitefly on the eggplant leaves, there was a significant mutual relationship that occurred under the agro-ecological system particularly under the rain shelter structure. Generally, whitefly was found to be a great major pest when compared to its competitors (aphid and thrips), because it has the specific ability and unique strategies to sustain their population on the eggplant leaves throughout the cropping period.

\section{References}

Agrawal, A.A., Kobayashi, C. and Thaler, J.S. (1999). Influence of prey availability and induced host-plant resistance on omnivory by the western flower thrips. Ecology, $\quad 80(2), \quad 518-523 . \quad$ https:// doi.org/10.1890/0012-9658(1999)080

[0518:IOPAAI]2.0.CO;2

Alborn, H.T., Turlings, T.C.J., Jones, T.H., Stenhagen, G., Loughrin, J.H. and Tumlinson, J.H. (1997). An elicitor of plant volatiles from beet armyworm oral secretion. Science, 276(5314), 945-949. https:// doi.org/10.1126/science.276.5314.945

Antony, B., Palaniswami, M.S. and Henneberry, T.J. (2003). Eretmocerus transvena (Hymenoptera: Aphelinidae) development on different Bemisia tabaci Gennadius (Homoptera: Aleyrodidae) instar. Environmental Entomology, 32(3), 584-591. https:// doi.org/10.1603/0046-225X-32.3.584

Aquilino, K.M., Cardinale, B.J. and Ives, A.R. (2005). Reciprocal effects of host plant and natural enemy diversity on herbivore suppression: An empirical study on a model tritrophic system. Journal Oikos, 108(2), 275-282. https://doi.org/10.1111/j.00301299.2005.13418.x

Arno, J., Arino, J., Espanol, R., Marti, M. and Alomar, O. (2000). Conservation of Macrolophus caliginosus Wagner (Het.Miridae) in commercial greenhouses during tomato crop-free periods. Bulletin OILB/ SROP, 23(1), 241-246.

Bogran, C.E. and Heinz, K.M. (2000). Whiteflies: House and Landscape Pests. Texas Cooperative Extension; B-6127. Retrieved from Extension Entomology: http://insects.tamu.edu

Castane, C., Alomar, O., Goula, M. and Gabarra, R.
(2004). Colonization of Tomato Greenhouses by the Predatory Mirid Bugs Macrolophus caliginosus and Dicyphus tamaninii. Department de Biologia Animal, Spain. Biological Control, 30(3), 591-597. https://doi.org/10.1016/j.biocontrol.2004.02.012

Coudriet, D.L., Meyerdirk, D.E., Prabhaker, N. and Kishaba, A.N. (1986). Bionomics of sweet potato whitefly (Homoptera: Aleyrodidae) on weed hosts in the Imperial Valley, California. Environmental Entomology, 15(6), 1179-1183. https:// doi.org/10.1093/ee/15.6.1179

Coudriet, D.L., Prabhaker, N., Kishaba, A.N. and Meyerdirk, D.E. (1985). Variation in developmental rate on different hosts and overwintering of the sweet potato whitefly, Bemisia tabaci (Homoptera: Aleyrodidae). Environmental Entomology, 14(4), 516-519. https://doi.org/10.1093/ee/14.4.516

Dicke, M. and Joop van Loon, J.A. (2000). Multitrophic effects of herbivore-induced plant volatiles in an evolutionary context. Laboratory of Entomology, Wageningen University, Netherlands. Entomologia Experimentalis et Applicata, 97(3), 237-249. https:// doi.org/10.1046/j.1570-7458.2000.00736.x

Gerling, D. (1967). Bionomics of the whitefly-parasite complex associated with cotton in Southern California (Homoptera: Aleurodidae; Hymenoptera: Aphelinidae). Annals of the Entomological Society of America, 60(6), 1306-1321. https://doi.org/10.1093/ aesa/60.6.1306

Gerling, D. (1985). Parasitoids attacking Bemisia tabaci (Hom.: Aleyrodidae) in Eastern Africa. Entomophaga, 30(2), 63-165. https:// doi.org/10.1007/BF02372249G

Gerling, D. (1986). Natural enemies of Bemisia tabaci, Biological Characteristics and Potential as Biological Control Agents: A review. Agriculture, Ecosystems and Environment, 17(1-2), 99-110. https:// doi.org/10.1016/0167-8809(86)90031-9

Gerling, D. (1990). Natural enemies of whiteflies: predators and parasitoids. In Gerling, D. (Ed.) Whiteflies their Bionomics, Pest Status and Management, p. 147-186. Andover, UK: Intercept Ltd.

Gerling, D. and Horowitz, A.R. (1984). Yellow traps for evaluating the population levels and dispersal patterns of Bemisia tabaci (Gennadius) (Homoptera: Aleyrodidae). Annals of the Entomological Society of America, 77(6), 753-759. https://doi.org/10.1093/ aesa/77.6.753

Gerling, D., Alomar, O. and Arnò, J. (2001). Biological control of Bemisia tabaci using predators and parasitoids. Crop Protection 20(9), 779-799. https:// 
doi.org/10.1016/S0261-2194(01)00111-9

Godfrey, L.D., Summers. C.G., Jimenez. M.J., Frate, C.A. and Wright, S.D. (2002). Corn thrips. UC Pest Management Guidelines. Retrieved from University of California Agriculture and Natural Resources website: http://www.ipm.ucdavis.edu/PMG/ r1 13300711.html

Harrison, S., Hasting, A. and Strong, D.R. (2005). Spatial and temporal dynamics of insect outbreaks in a multitrophic system: tussock moths, ghost moth, and their natural enemies on bush lupines. Annales Zoologici Fennici, 43(4), 409-419.

Hoddle, M.S. (1999). The biology and management of Silverleaf whitefly, Bemisia agentifolii Bellows and Perring (Homoptera:Aleyrodidae) on greenhouse grown ornamentals. Retrieved from https:// biocontrol.ucr.edu/silverleaf-whitefly

Horowitz, A.R., Podoler, H. and Gerling, D. (1984). Life Table Analysis of the tobacco whitefly Bemisia tabaci (Gennadius) in cotton fields in Israel. Acta Ecological/Ecologia Applicata, 5(3), 221-233.

Hunter, M.S. and Kelly, S.E. (1998). Hyperparasitism by an exotic autoparasitoid: secondary host selection and the window of vulnerability of conspecific and native heterospecific hosts. Entomologia Experimentalis et Applicata, 89(3), 249-259. https:// doi.org/10.1046/j.1570-7458.1998.00406.x

Khoo, K.C., Ooi, P.A.C. and Ho, C.T. (1991). Crop pests and their management in Malaysia, p. 64-65. Cornell University, USA: Tropical Press.

Li, S.-J., Xue, X., Ahmed, M.Z., Muhammad, Z.A., Ren, S.X., Du, Y.-Z., Wu, J.-H., Cuthbertson, A.G.S. and Qiu, B.L. (2011). Host plants and natural enemies of Bemisia tabaci (Hemiptera: Aleyrodidae) in China. Insect Science, 18(1), 101-120. https:// doi.org/10.1111/j.1744-7917.2010.01395.x

Li, S.J., Xue, X., Ahmed, M.Z., Ren, S.X., Du, Y.Z., Wu, J.H., Cuthbertson, A.G.S. and Qiu, B.L. (2011). Host plants and natural enemies of Bemisia tabaci (Hemiptera: Aleyrodidae) in China. Insect Science, 18(1), 101-120. https://doi.org/10.1111/j.17447917.2010.01395.x

Lopez-Avila, D.A. (1986). Taxonomy and Biology P3. In Cock, MJ.W. (Ed). Bemisia tabaci, A Literature Survey on the Cotton Whitefly with An Annotated Bibliography. Ascot UK: CAB International Institute of Biological Control.

Lucas, E. and Alomar, O. (2002). Impact of the presence of Dicyphus tamaninii Wagner (Heteroptera: Miridae) on Whitefly (Homoptera: Aleyrodidae) predation by Macrolophus caliginosus (Wagner) (Heteroptera: Miridae). Biological Control, 25(2),
123-128. https://doi.org/10.1016/S1049-9644(02) 00054-3

Mau, R.F.L. and Kessing, J.LM. (2000). Myzus persicae (Sulzer). Retrieved from website: http:// www.extento.hawaii.edu/kbase/crop/Type/ myzus.html

McAuslane, H.J. and Smith, H.A. (1995). Sweet potato Whitefly B biotype of silverleaf whitefly, Bemisia tabaci (Gennadius) or Bemisia argentifolii Bellows and Perring (Insecta: Homoptera: Aleyrodidae). Retrieved from University of Florida website: https://edis.ifas.ufl.edu/pdffiles/IN/IN28600.pdf

McDonough, M.J., Gerace, D. and Ascerno, M.E. (2003). Whiteflies in commercial greenhouse poinsettia production. Retrieved from University of Minnesota website: http://cues.cfans.umn.edu/old/ extpubs/7373whiteflies/DG7373.html

Mohd Rasdi, Z. (2005). Biology, Distribution and effect of selected insecticides against whiteflies (Trialeurodes vaporariorum Westwood and Bemisia tabaci Gennadius) on brinjal (Solanum melongena). Malaysia: Universiti Teknologi MARA, PhD Dissertation.

Mohd Rasdi, Z., Fauziah, I., CheSalmah M.R., Fairuz, K., Saiful Akbar, M.S., Md Jamaludin, B. and Kamaruzaman, J. (2009). Population ecology of whitefly, Bemisia tabaci, (Homoptera: Aleyrodidae) on brinjal. Journal of Agricultural Science, 1(1), 2732. https://doi.org/10.5539/jas.v1n1p27

Mohd Rasdi, Z., Ismail, R., Syahrizan, S., Nur Farhamizah A., Farahida, Z., Muhammad Aliuddin, B., Shafiq, S. and Che Salmah, M.R. (2006). Effect of nutrient and triggered eggplant defense system by different pre-infestation on the activities of whitefly parasitism. International Journal of Nutrition and Agriculture Research, 3(2), 2016, 67 - 79.

Moretti, R. and Calvitti, M. (2008). Intrinsic competition between the parasitoids Eretmocerus mundus and Eretmocerus Formosa in Bemisia tabaci. Entomologia Experimentalis et Applicata, 129(1), 44 -53. https://doi.org/10.1111/j.15707458.2008.00745.x

Nomikou, M., Janssen, A., Schraag, R. and Sabelis, M.W. (2001). Phytoseiid predators as potential biological control agents for Bemisia tabaci. Experimental and Applied Acarology, 25(4), 271291. https://doi.org/10.1023/A:1017976725685

Palumbo, J.C., Horowitz, A.R. and Prabhaker, N. (2001). Insecticidal control and resistance management for Bemisia tabaci. Crop Protection, 20(9), 739-765. https://doi.org/10.1016/S0261-2194(01)00117-X

Pearson, C.V. and Dyer, L.A. (2006). Trophic diversity 
in two grassland ecosystem. Journal of Insect

Science, $\quad 6(25), \quad 1-11 . \quad \mathrm{https}: / /$

doi.org/10.1673/2006_06_25.1

Sandra, D.S. and Ramon, C.L. (1987). SAS system for elementary statistical analysis. 2nd ed. SAS Institute.

Syed Abdul Rahman, S.A.R., Sivapagasam, A., Loke, W.H. and Ruwaida, M. (2000). Whiteflies in Malaysia. Paper presented at the Plant Resource Management Conference Hilton, 23 - 24 November. Kuching, Sarawak, Malaysia: Malaysian Plant Protection Society.

Takabayashi, J., Dicke, M. and Posthumus, M.A. (1991). Variation in composition of predator-attracting allelochemicals emitted by herbivore-infested plants: relative influenced of plants and herbivore. Chemoecology, 2, 1-6. https://doi.org/10.1007/ BF01240659

Zang, L.S. and Liu, T.X. (2009). Food-deprived hostfeeding parasitoids kill more pest insects. Biocontrol Science and Technology, 19(6), 573-583. https:// doi.org/10.1080/09583150902912673

Zar, J.H. (2010). Biostatistical analysis, $5^{\text {th }}$ ed. USA: Pearson. 